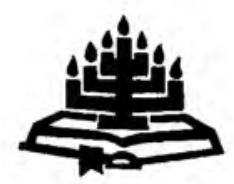

\title{
Die bydrae van prof. J.A. van Rooy in kerk, koninkryk, sending en teologie
}

Flip Buys

Mukhanyo Teologiese Kollege

KWANDEBELE

Jacobus Albertus van Rooy is op 25 Julie 1932 te Ventersburg gebore as die seun van ds. en mev. Jacs van Rooy. Sy moeder is oorlede toe hy nog 'n jong seun was. Hy het skoolgegaan op Brits en Pietersburg en later aan die PU vir CHO sy tersiêre opleiding ondergaan, terwyl hy hom voorberei het om predikant te word.

Op 15 Desember 1956 is hy getroud met Regina Kruger en uit die huwelik is twee dogters en twee seuns gebore.

\section{Sy roeping tot sendeling}

Hoe het sy roepingsgevoel eintlik ontstaan?

Op 14-jarige ouderdom kom hy onder die indruk van die geweldige omvang van 'n dreigende rassekonflik in Suid-Afrika. Omdat hy reeds 'n toegewyde gelowige was, soek hy antwoorde in die Bybel en by die Here. Hy kom tot die oortuiging dat die vernaamste bydrae wat hy sou kon maak om die konflik te vermy, is om die evangelie van God se genade deur Jesus Christus aan swart mense te verkondig. Hy sê self dat hy later besef het dat dit 'n totaal verkeerde en onbybelse motivering is om sending te doen. Immers, as ons sending doen omdat ons olie op die stormwaters van rassekonflik wil werp, dan is dit ten diepste 'n selfsugtige motief: ons wil dan naamlik sending doen om ons eie belang te dien. In sy groot genade kan die Here egter soms in sy voorsienigheid ons werk in sy koninkryk gebruik ten spyte van die verkeerde motiewe waarmee ons daarmee begin het.

In dieselfde tyd het hy 'n boekie gelees wat 'n lewenslange indruk op hom gemaak het en sy sterk sendingroeping blywende stukrag gegee het. Dit is die boek met die titel: Do not say: The church's excuse for neglecting the heathen. 
Sy lewe is in 'n groeiende mate gekenmerk deur eerbied en ontsag vir die Here en 'n passie om onbereikte mense met die evangelie te bereik.

Toe hy as teologiese student op Potchefstroom gestudeer het, het hierdie roeping ook gou duidelik geword. Medestudente het spottend van hom gesê: "As Koos van Rooy 'n swart mens sien, kry hy sommer so 'n waterige uitdrukking in sy oẹ!"

\section{Bediening}

Sy eerste beroep as bedienaar van die Woord is dan ook dadelik 'n sendingroeping. Hy word in 1957 deur 'n sendingkombinasie van die Gereformeerde Kerke Brooklyn en Sunnyside beroep en volgens artikel $7 \mathrm{KO}$ uitgestuur as sendeling na Siloam in Venda waar wyle prof. Hugo du Plessis reeds 'n aantal jare gewerk het.

Sy besondere gawe om tale te bemeester het reeds daaruit geblyk dat hy sy intreepreek in Venda voorberei het, dit feitlik gememoriseer het en in byna foutlose Venda voorgedra het. Sy verleentheid was groot toe gemeentelede na die diens spontaan in Venda met hom gesprekke aangeknoop het en hy nie met hulle kon kommunikeer nie. (Na aanleiding van sy vloeiende voordrag het hulle aanvaar hy verstaan Venda seker reeds goed as hy so vlot in Venda kon preek.)

In daardie jare was Venda nog ongerepte natuur. Daar was nie paaie nie en hy moes kilometers stap om sy werk te doen. Dit het meer kere gebeur dat hy aan die einde van 'n naweek tussen 60-70 km gestap het om mense met die evangelie te bedien. Dikwels het hy op Sondae 10-12 km tussen verskillende bedieningspunte gestap (om dan soms net vir drie vrouens te preek).

Deur sy inisiatief het die Christelijke Gereformeerde Kerke in Nederland in dié tyd begin om geneeshere na die Siloam-hospitaal te stuur. Dr. Evert Helms wat die hoof van die hospitaal geword het en sy eggenote het vir jare lank baie geseënde en gewaardeerde werk gedoen en is vandag nog persoonlike vriende van die Van Rooys.

In 1963 is hy deur 'n kombinasie van die Gereformeerde Kerke JohannesburgNoord en Roodepoort beroep met die opdrag om as sendeling in Soweto te werk. Sy opdrag was om veral toerustingswerk te doen.

In 1966 is hy deur die Christelijke Gereformeerde Kerk Hoogeveen in samewerking met die Zendingsdeputaten van die Sinode van die CGKN beroep om terug te keer na Venda. Nou was sy opdrag om hom toe te spits op opleiding en die opstel van literatuur vir die jong kerke in Venda. Uit sy vervulling van hierdie roeping het die Iyani Bybelskool in Sibasa tot stand gekom, wat vandag nog van sleutelbetekenis is vir die Gereformeerde Kerke in Venda. Behalwe diverse 
kursusse vir ampsdraers word daar deesdae selfs jong lidmate as sendelinge opgelei om vir 'n jaar lank in Mosambiek sendingwerk te gaan doen. Van die literatuur wat hy destyds daar geskryf het, is later met groot vrug ook baie wyd deur die Soweto Bible School van die Gereformeerde Kerk Linden gebruik. Op die oomblik word dit nog wyer versprei deur die Nehemiah Bible Institute in Wellington as deel van 'n korrespondensiekursus vir voorgangers van kerke in Afrika.

In 1975 aanvaar hy 'n beroep as hoogleraar in Ou-Testamentiese vakke aan die destydse Hammanskraalse Teologiese Skool waar predikante van die jong Gereformeerde Kerke uit die destydse gebiede van die Sinodes Soutpansberg, Middellande en Suidland opgelei is. Met die samesmelting van die Hammanskraalse en Potchefstroomse Teologiese Skole word hy professor in Sendingwetenskap aan die PU vir CHO.

Deur die jare heen het hy in verskillende Deputaatskappe van meerdere vergaderings van die Gereformeerde Kerke in Suid-Afrika gedien, later veral as adviseur en het hy baie belangrike bydraes gelewer. Die rigtinggewende prinsipiële besluite wat die Nasionale Sinode van die GKSA met sy vergadering van 1988 (vgl. Art 74, 362 e.v.) geneem het, is veral van groot betekenis.

\section{Akademiese loopbaan}

Hy was en is sy lewe lank 'n baie ywerige student.

In 1964 behaal hy die Th.M.-graad in Teologie met 'n verhandeling oor Sinkretisme in Vendaland.

In 1971 behaal hy sy eerste Th.D.-graad met 'n proefskrif met die titel: Language and culture in the communication of Christ's message as illustrated in the Venda Bible. Alhoewel hy hierdie graad onder promotorskap van wyle prof. Hugo du Plessis behaal het, het die internasionaal bekende prof. Eugene Nida in sy leiding die deurslag gegee vir die hooflyne van hierdie proefskrif.

In 1995 behaal hy 'n tweede Th.D. met die titel: Jahweh and Modimo. The relationship between God and man in the Old Testament seen in the context of African concepts of God.

Deur die jare het 'n groot aantal wetenskaplike en populêr-wetenskaplike artikels uit sy pen verskyn. Verskeie daarvan is ook in In die Skriflig gepubliseer. Sy verskillende en uitgebreide bydraes oor die verskillende aspekte van transkulturele verkondiging van die evangelie in Afrika is enig in die kringe van die Gereformeerde Kerke in Suid-Afrika. 
Hy was van die stigting van die Suid-Afrikaanse Werkgemeenskap vir Sendingwetenskap 'n gewaardeerde lid en medewerker en het deur die jare heen verskeie voordragte by kongresse gelewer wat in die tydskrif Missionalia en in ander sendingtydskrifte gepubliseer is.

Hy is ook goed bekend by buitelandse studente uit Korea en Suid-Amerika wat graag by hom besoek aflê om advies te vra oor sendingprojekte en navorsing in Sendingwetenskap.

\section{Bybelvertaling}

Van die heel belangrikste bydraes tot die uitbreiding van die koninkryk is sekerlik sy betrokkenheid by die Bybelvertaling in Venda sedert 1973. Sy besondere gawe om tale te bestudeer het hom uitnemend geskik gemaak vir hierdie werk. Hy het onder andere drie maande in Jerusalem gaan leer om moderne Hebreeus te praat.

Hy het ook geleer om Italiaans te praat en 'n Bybelkommentaar op Genesis uit sy pen is ook in Nederlands gepubliseer.

Wat die Venda-Bybelvertaling betref, het hy deurgaans die leiding geneem in hierdie magistrale projek. Hy is hierin gekenmerk deur indringende en deeglike werk. Mense wat hom aan die werk gesien het, vertel dat hy behalwe die oorspronklike Hebreeus en Grieks meestal 10 ander vertalings vergelyk het voordat hy die betrokke gedeeltes in Venda vertaal het. Hy het ook altyd groot klem daarop gelê dat Bybelvertaling spanwerk is en daarom het hy gereeld ' $n$ hele verskeidenheid bekwame medewerkers uitgesoek om saam te werk aan die projek. Van die hoogtepunte in sy bediening is die verskyning van die Nuwe Testament in Venda in 1988 en die verskyning van die hele Bybel in Venda D.V. in 1998 .

Sedert 1996 neem hy ook leiding met die Njungwe Bybelvertaling. Dit is 'n onbereikte taalgroep in die Tete-provinsie in Mosambiek.

\section{Besondere belangstelling in die werk van die Heilige Gees en herlewing en reformasie in die kerk}

Vra jy Koos van Rooy self uit oor wat hy as die hoogtepunte van sy bediening beskou, dan noem hy met diep dankbaarheid die geestelike herlewing wat daar sedert 1966 in die Gereformeerde Kerke in Venda gekom het, veral onder die jeug in die kerke. Daar het sedert dié tyd 'n ongekende groei in geloofsdiepte en in die omvang van getalle gekom. In die jare van die politieke stryd het die Gereformeerdes in Venda ontsaglik gely onder die druk en vervolging van leiers in die politieke rewolusie, maar ten spyte daarvan het dit die groei in die kerk aangehelp 
Hierdie ontwikkelinge in die kerke in Venda het hom ' $n$ besondere belangstelling laat ontwikkel in die werk van die Heilige Gees en die verskynsel van tye van eb en vloed in die werking van die Heilige Gees in die wêreld deur die eeue heen en deur die loop van die geskiedenis. Dit het daartoe gelei dat hy van die hele verskynsel van herlewing 'n indringende studie gemaak het, onder andere deur eerstehands die werk by KwaSizabantu in Natal te gaan ondersoek. Hy het 'n studiebeurs van die RGN daarvoor ontvang en in 'n straal van $50 \mathrm{~km}$ rondom KwaSizabantu vir drie maande lank in die gebied te voet rondgegaan en by gewone gesinne tuisgegaan. Deur gesprekke en kontak met mense op voetsoolvlak het hy 'n peiling gemaak van die invloed van die gebeure by KwaSizabantu op hulle alledaagse lewens. Sy bevindinge is later in 'n publikasie, sowel as in akademiese artikels gepubliseer. Hy het in 'n verskeidenheid ander voordragte gewaarsku teen valse idees oor herlewing en terselfdertyd die noodsaak van gebed om egte herlewing beklemtoon.

\section{Soms omstrede}

Soos wat dit met oorspronklike en prinsipiële denkers gaan, was hy soos 'n egte profeet soms ook omstrede. In die vroee jare van sy bediening is hy vanwee sy anti-rassistiese (gewoon menslike) optrede teenoor swart mense in sommige kringe as "liberaal" afgemaak (soms bloot omdat hy swart mense met die hand gegroet het of 'n geleentheid gegee het om saam met hom na kerklike byeenkomste te ry.)

Vanweë sy beklemtoning van die noodsaaklikheid van persoonlike geloofstoeëiening van die beloftes van die verbond vir elke verbondskind, die krag van 'n gereelde, innige persoonlike gebedsomgang met die Here en die roeping van elke gelowige om 'n getuie van Jesus Christus te wees, is hy soms beskuldig van Piêtisme of Metodisme of selfs Arminianisme. Sy belangstelling in die werk van die Heilige Gees het hom soms die beskuldiging van 'n aanhanger van die Charismatiese Beweging op die hals gehaal. Sy bewoënheid oor Moslems en sy ywer om hulle te evangeliseer het hom ook skerp kritiek op die hals gehaal.

Op sy nederige dog skerp manier het hy altyd op die navrae geantwoord en telkens het kerklike vergaderings die klagtes tersyde gestel.

\section{Voortgaande ywer vir die uitdra van die Woord na onberelkte mense}

Sy wye kennis van die Afrika-kultuur, van sending oor die algemeen en van Bybelvertaling in die besonder word steeds erken deur die feit dat hy onlangs deur die Summer Institute of Linguistics aangestel is as konsultant vir raadgewing en die beplanning van verskillende Bybelvertalingsprojekte in Suidelike Afrika, veral in Mosambiek. 
Hy is ook uitgenooi om as gasdosent 20 voordragte in verband met verskeie aspekte van die sending te gaan lewer by die Teologiese Skool van die Presbiteriaanse Kerke in Korea te Pusan.

\section{Belangstelling in bome en plante}

Hy het ook 'n groot belangstelling in en 'n wye kennis van die verbouing van proteas en vrugtebome, veral veselperskes. Hy is seker die eerste Gereformeerde teologiese professor wat ook al landbou- en boereverenigings oor tegniese aspekte van vrugteverbouing toegespreek het! Ook protea-kwekers praat met respek van sy kennis op hierdie gebied. Protea-kruisings wat hy gekweek het, is al na Australië uitgevoer.

Sy woning op die plaas Sederkrans, waar sy eggenote met groot ywer die boerdery bestuur wanneer hy met kerklike en teologiese verpligtinge uitstedig moet wees, is vir besoekers iets van 'n besoek aan die tuin van Eden.

Mag hy en sy eggenote Regina nog lang jare vir mekaar, vir hulle kinders en kleinkinders en hulle medegelowiges gespaar bly. Mag die die kerke veral in hulle uitdra van die Woord ook nog veel put uit Koos van Rooy se advies en publikasies. 